\title{
First report of Toxomerus dispar (Fabricius, 1794) (Diptera: Syrphidae) preying Spodoptera frugiperda (J.E. Smith, 1797) (Lepidoptera: Noctuidae) in laboratory
}

\author{
T. A. Campos ${ }^{a}$, T. E. Ueda ${ }^{a}$, D. M. Zirondi Filho ${ }^{a}$, O. C. Bortolotto ${ }^{a *}$, \\ A. Pasini and M. N. Morales ${ }^{b}$ \\ a Departamento de Agronomia, Universidade Estadual de Londrina - UEL, Rodovia Celso Garcia Cid, \\ Pr 445m 380, CP 10011, CEP 86057-970, Londrina, PR, Brazil \\ ${ }^{\text {b}}$ Departamento de Entomologia, Universidade Federal de Lavras - UFLA, CP 3037, \\ CEP 37200-000, Lavras, MG, Brazil \\ *e-mail: bortolotto.orcial@gmail.com
}

Received: November 6, 2015 - Accepted: February 16, 2016 - Distributed: May 31, 2017 (With 1 figure)

The fall armyworm Spodoptera frugiperda (Smith, 1797) (Lepidoptera: Noctuidae) is one of the most important pests in Brazilian maize fields that causes damage to approximately $57 \%$ of the crop (Cruz et al., 1999). However, several biological control agents occur freely in agroecosystems and are known to suppress the $S$. frugiperda population (Dequech et al., 2004; Bortolotto et al., 2014). Among the predator insects, hoverflies have been reported to occur in maize fields but are usually associated with aphid infestation (Swaminathan et al., 2015). Thus far, few studies have investigated hoverflies preying on lepidopteran pests, and the spectrum of preys examined is unclear. To our knowledge, this is the first report of Toxomerus dispar larvae (Fabricius, 1794) (Diptera: Syrphidae) preying on S. frugiperda caterpillars (Figure 1).

Thirty specimens of hoverfly larvae were collected from 100 plants (in $\mathrm{V}_{9}-\mathrm{V}_{10}$ phenological stage) in a maize field, located in Londrina (2320'601' S 51 $12^{\circ}$ '764' W), Paraná State, in April 2013. In laboratory, the hoverfly larvae were segregated using a brush, and then individually placed in Petri dishes (diameter: $10 \mathrm{~cm}$ ) under controlled conditions $\left(25^{\circ} \mathrm{C} \pm 2{ }^{\circ} \mathrm{C}, 60 \% \pm 20 \%\right.$ humidity, and a 12 -h photoperiod). A piece of moistened cotton ball was placed in each Petri dish along with a maize leaf disc $\left(10 \mathrm{~cm}^{2}\right)$ daily infested with 10 aphids, and the larvae were allowed

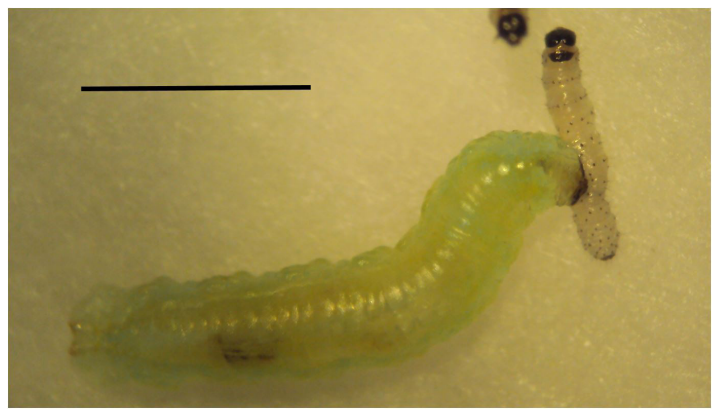

Figure 1. Larva of third instar of Toxomerus dispar (Fabricius, 1794) (Diptera: Syrphidae) preying first instar of Spodoptera frugiperda (Smith, 1797) (Lepidoptera: Noctuidae) caterpillar in laboratory. Bar $=2 \mathrm{~mm}$. to feed aphids until they reach the third-instar stage (due to the high aggressivity of $S$. frugiperda against newly hatched hoverfly larvae). Thereafter, first and second instar S. frugiperda caterpillars (obtained from the Laboratory of Embrapa Soybean, Londrina, PR, Brazil) were provided ad libitum as feed to hoverfly larvae (Figure 1), until they reached the pupal stage or died.

Toxomerus dispar larvae consumed two caterpillars in $24 \mathrm{~h}$, on average, and the larval viability was found to be $76.7 \%$, which indicated that $S$. frugiperda caterpillars have high nutrient content and may have facilitated the development of hoverfly larvae. T. dispar larvae that reached the pupal stage were retained in the same Petri dishes until adults emerged. The adults were then transferred to plastic micro tubes containing $70 \%$ alcohol to kill them. These individuals were then identified by comparison with the other specimens stored in the museum at the State University of Londrina (UEL) and were identified as $T$. dispar, which prey on other insects such as aphids (Rojo et al., 2003; Swaminathan et al., 2015) and Diatraea spp. caterpillars (Guilding, 1828) (Lepidoptera: Crambidae) (Rojo et al., 2003). Therefore, this report indicates that $S$. frugiperda is a newly identified prey of hoverfly larvae. In conclusion, we suggest further investigation of the bioecology of this predator in maize fields. Moreover, assays within an isolated area of approximately $1 \mathrm{~m}^{2}$ under controlled conditions could corroborate the use of these predators in the field.

\section{Acknowledgements}

We are grateful to CAPES for providing the post-graduate scholarship support first, second and fourth authors.

\section{References}

BORTOLOTTO, O.C., MENEZES JUNIOR, A.O., HOSHINO, A.T., CARVALHO, M.G., POMARI-FERNANDES, A. and SALGADO-NETO, G., 2014. Sugar solution treatment to attract natural enemies and its impact on fall armyworm Spodoptera frugiperda in maize fields. Interciencia, vol. 39, no. 6, pp. 416-421.

CRUZ, I., FIGUEIREDO, M.L.C., OLIVEIRA, A.C. and VASCONCELOS, C.A., 1999. Damage of Spodoptera frugiperda 
(Smith) in different maize genotypes cultivated in soil under three levels of aluminum saturation. International Journal of Pest Management, vol. 45, no. 4, pp. 293-296. http://dx.doi. org/10.1080/096708799227707.

DEQUECH, S.T.B., SILVA, R.F. and FIUZA, L.M., 2004. Occurrence of Spodoptera frugiperda (J. E. Smith) (Lep. Noctuidae) parasitoids in maize crops in Cachoeirinha, RS, Brazil. Ciência Rural, vol. 34, no. 4, pp. 1235-1237. http://dx.doi.org/10.1590/ S0103-84782004000400042.
ROJO, S., GILBERT, F., MARCOS-GARCÍA, M.A., NIETO, J.M. and DURANTE, M.P.M., 2003. A world review of predatory hoverflies (Diptera, Syrphidae: Syrphinae) and their prey. Alicante: Universidad de Alicante. 319 p.

SWAMINATHAN, R., MEENA, A. and MEENA, B.M., 2015. Diversity and predation potential of major aphidophagous predators in maize. Applied Ecology and Environmental Research, vol. 13, no. 4, pp. 1069-1084. http://dx.doi.org/10.15666/ aeer/1304_10691084. 